\title{
15. PETROLOGY AND GEOCHEMISTRY OF BASALTIC ROCKS FROM RIO GRANDE RISE, SOUTH ATLANTIC: DEEP SEA DRILLING PROJECT LEG 72, HOLE 516F1
}

\author{
Geoffrey Thompson and Susan Humphris, Chemistry Department, Woods Hole Oceanographic Institution, \\ Woods Hole, Massachusetts \\ and \\ Jean-Guy Schilling, Graduate School of Oceanography University of Rhode Island, Kingston, Rhode Island
}

\begin{abstract}
Basalts from Hole 516F, DSDP Leg 72 on the Rio Grande Rise are tholeiitic in character but differ from normal mid-ocean ridge basalts in the South Atlantic in higher concentrations of incompatible elements such as $\mathrm{Ti}, \mathrm{K}, \mathrm{V}, \mathrm{Sr}$, $\mathrm{Ba}, \mathrm{Zr}, \mathrm{Nb}$, and light rare-earth elements and in lower concentrations of $\mathrm{Mg}, \mathrm{Cr}$, and $\mathrm{Ni}$. They contrast with previously reported basalts from the Rio Grande Rise, which were highly alkalic in character. The Rio Grande Rise basalts from Hole $516 \mathrm{~F}$ (age $84.5 \mathrm{Ma}$ ) are generally similar to basalts from the eastern end of the Walvis Ridge $(80-100 \mathrm{Ma})$. It is suggested that they either originated, like the Walvis Ridge, from a mantle hot spot that is different from the present-day hot spot (Tristan da Cunha) and that has changed composition with time, or from a spreading center that was shallow and chemically influenced by the adjacent hot spot, similar to the present-day Mid-Atlantic Ridge near the Azores and Tristan da Cunha.
\end{abstract}

\section{INTRODUCTION}

The Rio Grande Rise is one of the world's major aseismic ridges; it rises more than $3 \mathrm{~km}$ above the ocean floor. In reconstructions of the South Atlantic opening, the Rio Grande Rise in the western basin and the Walvis Ridge in the eastern basin have been explained as aseismic ridges related to passage of the plates over a hot spot (Dietz and Holden, 1970; Morgan, 1971). The island of Tristan da Cunha is thought to be the presentday expression of that hot spot. Morphologically the Rio Grande Rise is less well developed than the Walvis Ridge, but because of its east-west orientation across the water mass pathways of the western boundary current and because of the presence of the Vema Channel cutting through the Rise, it has played a major role in paleocirculation and paleoenvironments in the past. Recent seismic studies have shown that the Rio Grande Rise is bounded by major fracture zones, and it has been suggested that the Rise is related to volcanism along these fracture zones (LePichon and Hayes, 1971).

Before Leg 72 of the Deep Sea Drilling Project (DSDP), attempts to core the basement of the Rio Grande Rise had failed (Maxwell et al., 1970; PerchNielsen et al., 1977). Drilling at DSDP Site 357 during Leg 39 recovered basaltic fragments in a breccia in calcareous middle Eocene sediments. These fragments were found to be alkalic basaltic rocks probably erupted from an alkali-rich seamount in shallow water during the Eocene (Fodor and Thiede, 1977). Igneous rocks were also recovered by dredging in 1973 and were composed largely of basaltic fragments. These samples, composed of alkalic basalt, trachybasalt, and trachyandesite, are similar to rock types found on Tristan da Cunha (Fodor,

\footnotetext{
${ }^{1}$ Barker, P. F., Carlson, R. L., Johnson, D. A., et al., Init Repts. DSDP, 72: Washington (U.S. Govt. Printing Office).
}

Husler, et al., 1977). This dredge site at $30^{\circ} 26^{\prime} \mathrm{S}, 36^{\circ}$ $01^{\prime} \mathrm{W}$ is just west of Hole $516 \mathrm{~F}\left(30^{\circ} 16.59^{\prime} \mathrm{S}\right.$, $\left.35^{\circ} 17.11^{\prime} \mathrm{W}\right)$ and Site $357\left(30^{\circ} 00.25^{\prime} \mathrm{S}, 35^{\circ} 33.59^{\prime} \mathrm{W}\right)$ where the volcanic breccia was recovered. These locations are shown in Figure 1.

On the basis of their studies of the Site 357 breccia and the dredged rocks, Fodor, Husler, et al. (1977) suggested that the Rio Grande Rise represented a series of alkalic-basalt islands that formed and eventually subsided during rifting of the South Atlantic. Thiede (1977) has suggested that the Rio Grande Rise was a large island 2-3 km above sea level during Santonian to Campanian times (85-75 Ma). Fodor, Husler, and Kumar (1977) noted similarities between the dredged basalts and drilled breccias and suggested they might be from similar sources. They further noted that these samples were unlike mid-ocean ridge basalts but more like those recovered from the South Atlantic islands such as Tristan da Cunha and Gough. Samples previously reported from the Walvis Ridge (Hekinian, 1972) had alkaline characteristics similar to the Rio Grande Rise rocks; however, they also contained some rocks with tholeiitic affinities, suggesting differences between these two aseismic ridges. Frey and others (1974) and Schilling (1975) reported on basalts recovered from the South Atlantic basin at $30^{\circ} \mathrm{S}$ during DSDP Leg 3 (Fig. 1). They noted that these basalts, ranging in age up to $60 \mathrm{Ma}$, were typical mid-ocean ridge basalts.

In contrast to the previous studies of rocks from the Rio Grande Rise, preliminary work on the igneous rocks recovered at DSDP Site 516F, Leg 72 (Barker et al., 1981) suggested that these samples had tholeiitic affinities but with higher concentrations of incompatible elements such as $\mathrm{Ti}, \mathrm{P}, \mathrm{Zr}, \mathrm{Nb}, \mathrm{Y}, \mathrm{La}$, and $\mathrm{Ce}$ in comparison to typical mid-ocean ridge basalts (MORB). A Santonian-Campanian age (84.5 Ma) for basement is inferred from the age of overlying sediments and identifi- 


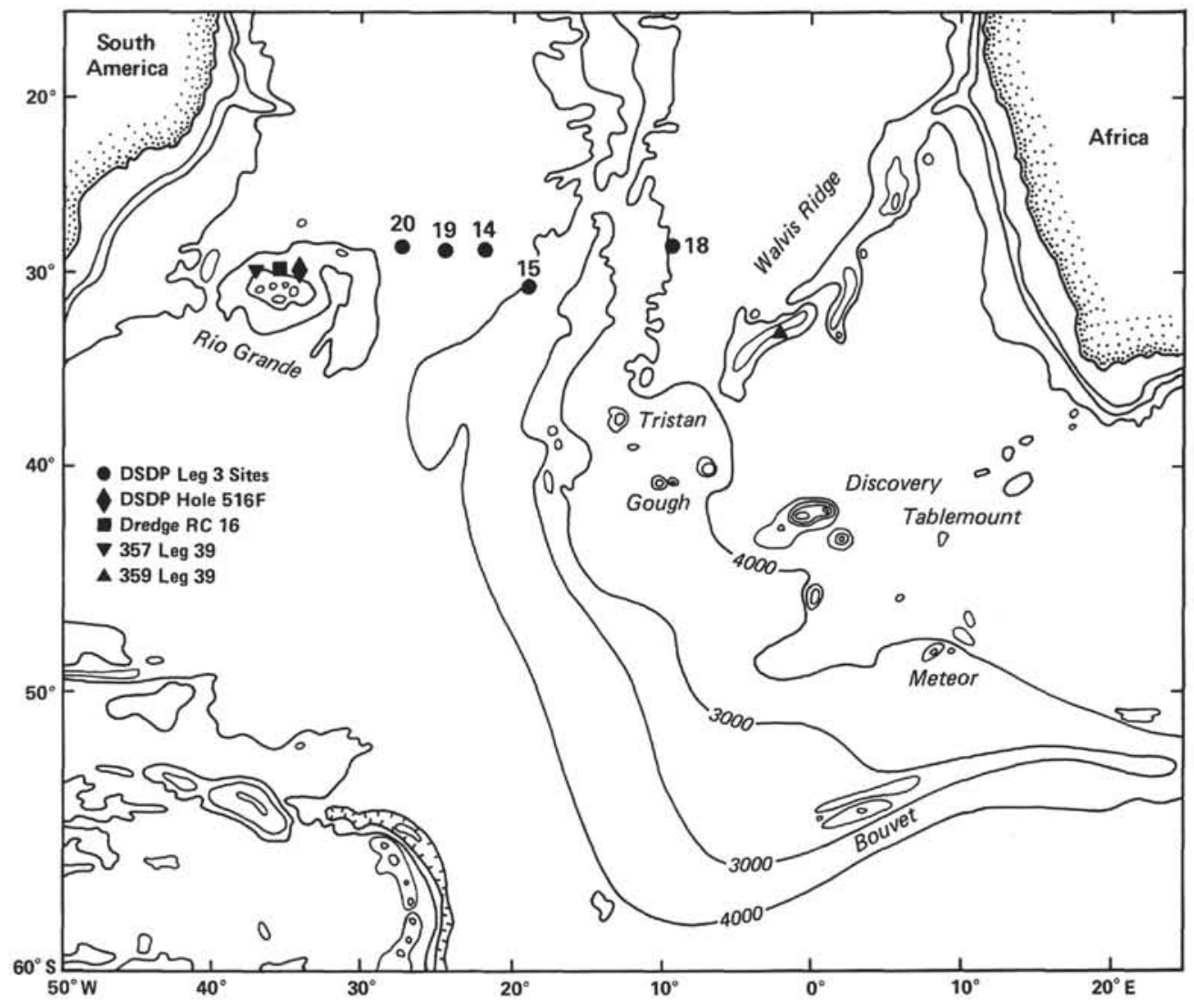

Figure 1. Map of the South Atlantic showing the position of Discovery Tablemount, DSDP Leg 3 sites, Dredge RC16, DSDP Leg 39 Sites 357 and 359, and DSDP Leg 72 Hole 516F.

cation of Magnetic Anomalies 33 and 34 to the east of the site (site chapter, Site 516, this volume).

In this paper, we present detailed petrologic and geochemical studies of 14 igneous rock samples from different stratigraphic levels in the cored basement of Hole $516 \mathrm{~F}$. The objectives of our study are (1) to understand the compositional variation within the flows recovered by drilling at this site; (2) to compare these rock compositions with those from the mid-ocean ridge at this latitude, with rocks recovered from the Walvis Ridge (the geographic counterpart of the Rio Grande Rise), with rocks from the South Atlantic islands, and with samples previously described from the Rio Grande Rise; and (3) to suggest a possible origin and history for this major oceanographic feature.

\section{PETROGRAPHY}

The principal minerals in the basalts from Leg 72 are plagioclase, clinopyroxene, and iron oxides; plagioclase is dominant. The rocks are generally glomerophyric, with plagioclase and occasional clinopyroxene phenocrysts occurring in small clusters within a fine-grained groundmass. Vesicles are rare in these samples, but those present are commonly filled with bright green clay minerals or calcite. Most of the samples studied were selected to avoid vein or vesicle contents.

Plagioclase phenocrysts are commonly euhedral or lath-shaped, and often show quite complex zoning. Optical properties suggest that they are labradorite. Pyrox- ene phenocrysts are less common, often making up only about $1 \%$ by volume. They are euhedral to subhedral and display simple twinning, as well as zoning. In the more weathered samples, both types of phenocrysts are partially replaced by calcite.

The groundmass consists of microlites of plagioclase, granular pyroxene, opaque minerals, and possibly glass in varying proportions. Much of what might be considered glass is replaced, mainly by calcite, although clay minerals are present in some samples.

The samples we have studied may be divided into two groups on the basis of the degree of crystallinity of the groundmass and the proportions of the constituent minerals. The upper unit extends from Sample 516F-126-2, $143-146 \mathrm{~cm}$ down to Sample 516F-127-4, 44-48 cm inclusive. It consists of basalts in which the groundmass is mainly plagioclase microlites and fine-grained, altered material dominated by calcite; clinopyroxene is minor. Fine-grained, subhedral to anhedral iron oxides are scattered throughout the groundmass and comprise up to $4 \%$ by volume. The lower unit extends from Sample $516 \mathrm{~F}-127-4,60-63 \mathrm{~cm}$ to the bottom of the hole. The groundmass in samples from the lower unit consists of plagioclase microlites and granular pyroxene with minor amounts of interstitial altered material. The iron oxides are coarser grained than in the upper unit and are often euhedral or needle-shaped. This unit appears less weathered than the upper unit, but they are extremely similar and could represent a single basaltic flow. 
The petrographic character of these samples differs markedly from typical MORB and shows none of the typical quench structures of lavas erupted on the deep sea floor (Bryan, 1972). The fine-grained altered groundmass may represent a chilled interstitial glass consistent with eruption in shallow water. However, the pervasive nature of the alteration and its dominance by calcite preclude definitive statements on the origin of the flow.

\section{METHODS}

The samples were selected at different levels in the core; we tried to avoid samples with obvious major alteration or veining. The samples were ground in agate and analyzed by X-ray fluorescence spectrometry. Accuracy for major elements is in the $0.5-3 \%$ range; for trace elements, it is in the $1-5 \%$ range, based on analysis of reference rocks. Details of the X-ray fluorescence technique have been described by Schroeder et al. (1980). The rare earth elements (REE) and Sc were determined by instrumental neutron activation analysis (INAA). Details of the technique have been described by Schilling and Ridley (1976).

\section{CHEMICAL ANALYSIS}

In Table 1, Part 1, we present the analyses for major elements. Because of the large amount of alteration, these analyses are presented on a volatile-free basis to make comparisons easier. Analyses of the volatiles are also presented so that the analyses may be recast into their original form if required. Trace element analyses are presented in Table 1, Part 2.

\section{DISCUSSION}

\section{Within-Site Variation}

Both the chemical analyses and petrographic studies of the Hole $516 \mathrm{~F}$ samples show that there are differences between samples from the upper part of the core and those lower in the core. The upper samples, up to and including $516 \mathrm{~F}-127-4,44-48 \mathrm{~cm}$, are marked by higher concentrations of $\mathrm{CO}_{2}$ and $\mathrm{H}_{2} \mathrm{O}^{+}$and higher $\mathrm{Fe}_{2} \mathrm{O}_{3} / \mathrm{FeO}$. Other distinct chemical differences indicate that it is not merely the degree of alteration that distinguishes the two groups. In Table 2, we show the average compositions of these two groups. Sample 516F-127-2, $83-88 \mathrm{~cm}$ has been omitted from the average of the upper group because it contains a high quantity of a green smectite, an alteration product that was carefully avoided in the other samples. Although this affects only the $\mathrm{K}_{2} \mathrm{O}$ and $\mathrm{Rb}$ contents, it clearly acts as a dilutant on the other element concentrations.

The concentration differences between the two groups are not large. They are within experimental errors for the rare earths. The slightly higher concentrations of $\mathrm{TiO}_{2}, \mathrm{Na}_{2} \mathrm{O}, \mathrm{V}, \mathrm{Zr}$, and $\mathrm{Nb}$ in the Group 1 samples could argue that this upper flow (if indeed these two groups represent two distinct flows) is more evolved in terms of fractional crystallization. However, this simple apparent enrichment in incompatible elements is accompanied by lower $\mathrm{SiO}_{2}, \mathrm{~K}_{2} \mathrm{O}, \mathrm{Rb}$, and $\mathrm{Y}$ contents and higher concentrations of incompatible elements such as $\mathrm{Cr}, \mathrm{Co}$, and $\mathrm{Ni}$ in the upper flow. Some of these differences are shown in Figures 2 and 3. It should be noted that the differences are not great between the two groups and these lavas are characterized by their high degree of crystallinity. Some of the chemical differences reflect alteration effects, some reflect differences in degree of crystal fractionation, and others probably reflect differences in modal content of individual minerals. Thus, although the differences are somewhat complex to explain, they are too small to affect the relative chemical characterization of the rocks of this hole compared to other rocks from the Rio Grande Rise or other parts of the South Atlantic.

\section{Regional Comparison}

On a standard alkalies versus silica diagram, Hole $516 \mathrm{~F}$ basalts are all found in the field of Hawaiian tholeiites (Fig. 4). Symbols representing previously recovered dredged rocks from the Rio Grande Rise (Fodor, Husler, et al., 1977) occur well into the field of Hawaiian alkali basalts, as do basalts from Tristan da Cunha, the Discovery Tablemount basalts, and many, but not all, of the Walvis Ridge basalts. Basalts from the Mid-Atlantic Ridge, including DSDP Leg 3 basalts, apparently have tholeiitic affinities similar to Hole 516F, although most have less total alkalies because of their very low $\mathrm{K}_{2} \mathrm{O}$ content.

However, the Rio Grande Rise basalts of Hole $516 \mathrm{~F}$, although they have tholeiitic major element affinities, are quite markedly enriched in incompatible trace elements compared to normal MORB and thus have many alkaline affinities, as shown in Table 3, which summarizes the comparative analyses of some of these South Atlantic basalts. Figure 5 clearly shows the marked enrichment in $\mathrm{TiO}_{2}$ and $\mathrm{Zr}$ of the Hole 516F Rio Grande Rise basalts compared to normal MORB. Also, in Figure 6 , the chondrite-normalized light rare-earth element (LREE) enrichment of the Rio Grande Rise basalts is quite distinctive compared to the flat or typically LREEdepleted MORB. Figure 6 indicates that the Rio Grande Rise basalts, although not quite as LREE-enriched, have REE distribution similar to the Walvis Ridge and Gough Island basalts. Data on some of the trace elements of the dredged alkaline basalts from the Rio Grande Rise are given in Table 4, and Figures 5 and 7. These analyses were done in our laboratory on splits of the powders analyzed by Fodor, Husler, and Kumar (1977) for major elements and kindly made available to us by Dr. Fodor.

Humphris and Thompson (1982) in their study of Walvis Ridge basalts noted a wide range of compositions from tholeiitic to alkaline. However, they did find systematic differences in composition in the different parts of the ridge. In particular, they noted that the eastern end of the Walvis Ridge (80-100 Ma) was quite distinct from the central and western sections and from the present-day hot spot at Tristan da Cunha. Figure 7 shows this feature best in a plot of $\mathrm{Nb}$ versus $\mathrm{Zr}$. These two elements are not markedly affected by alteration (Thompson, 1973), and their ratio is not markedly affected by fractional crystallization. Rather, they are good markers of the source region of the basalts (Erlank and Kable, 1979). The Hole $516 \mathrm{~F}$ basalts are distinct from the Mid-Atlantic Ridge basalts, which have a $\mathrm{Zr}$ / $\mathrm{Nb}$ ratio usually greater than 20 . These Rio Grande Rise 
Table 1. Basalt analyses from Hole 516F.

\begin{tabular}{|c|c|c|c|c|c|c|c|c|c|c|c|c|c|c|}
\hline \multirow[b]{2}{*}{ Element } & \multirow{2}{*}{$\begin{array}{c}126-2 \\
143-146\end{array}$} & \multirow[b]{2}{*}{$\begin{array}{c}126-3 \\
6-9\end{array}$} & \multirow[b]{2}{*}{$\begin{array}{l}126-3 \\
41-44\end{array}$} & \multirow[b]{2}{*}{$\begin{array}{r}127-2 \\
83-88\end{array}$} & \multicolumn{3}{|c|}{$\begin{array}{l}\text { Core-section } \\
\text { (interval in } \mathrm{cm} \text { ) }\end{array}$} & \multirow[b]{2}{*}{$\begin{array}{l}127-4 \\
60-63\end{array}$} & \multirow[b]{2}{*}{$\begin{array}{l}128-1 \\
25-28\end{array}$} & \multirow[b]{2}{*}{$\begin{array}{c}128-1 \\
122-126\end{array}$} & \multirow[b]{2}{*}{$\begin{array}{l}128-2 \\
51-56\end{array}$} & \multirow[b]{2}{*}{$\begin{array}{c}128-2 \\
130-135\end{array}$} & \multirow[b]{2}{*}{$\begin{array}{r}128-3 \\
44-48\end{array}$} & \multirow[b]{2}{*}{$\begin{array}{l}128-3 \\
73-75\end{array}$} \\
\hline & & & & & $\begin{array}{l}127-3 \\
68-72\end{array}$ & $\begin{array}{c}127-3 \\
97-102\end{array}$ & $\begin{array}{l}127-4 \\
44-48\end{array}$ & & & & & & & \\
\hline \multicolumn{15}{|c|}{ Major element analyses (on a volatile-free basis after ignition at $1000^{\circ} \mathrm{C}$; in wt. $\%$ ) } \\
\hline $\mathrm{SiO}_{2}$ & 49.64 & 50.26 & 50.43 & 48.92 & 49.45 & 49.96 & 48.68 & 51.05 & 51.86 & 51.25 & 51.77 & 49.20 & 51.81 & 51.62 \\
\hline $\mathrm{TiO}_{2}$ & 2.69 & 2.72 & 2.82 & 2.45 & 2.63 & 2.63 & 2.51 & 2.27 & 2.30 & 2.23 & 2.37 & 2.50 & 2.41 & 2.35 \\
\hline $\mathrm{Al}_{2} \mathrm{O}_{3}$ & 16.24 & 16.46 & 16.19 & 16.86 & 16.45 & 15.66 & 15.84 & 13.89 & 14.16 & 13.93 & 14.13 & 14.84 & 13.77 & 13.99 \\
\hline $\mathrm{FeO}^{\mathrm{a}}$ & 13.33 & 10.87 & 11.32 & 14.66 & 12.76 & 12.32 & 13.77 & 13.25 & 12.55 & 13.40 & 12.65 & 14.37 & 13.02 & 12.74 \\
\hline $\mathrm{MnO}$ & 0.17 & 0.13 & 0.14 & 0.19 & 0.11 & 0.12 & 0.20 & 0.23 & 0.19 & 0.23 & 0.19 & 0.25 & 0.20 & 0.19 \\
\hline $\mathrm{MgO}$ & 4.66 & 3.93 & 4.21 & 4.41 & 4.99 & 5.08 & 5.55 & 5.91 & 5.66 & 5.85 & 5.70 & 5.88 & 5.51 & 5.60 \\
\hline $\mathrm{CaO}$ & 10.18 & 11.96 & 11.13 & 8.11 & 10.04 & 10.81 & 10.29 & 10.53 & 10.63 & 10.44 & 10.64 & 10.14 & 10.47 & 10.57 \\
\hline $\mathrm{Na}_{2} \mathrm{O}$ & 2.92 & 3.00 & 2.99 & 2.46 & 2.95 & 2.90 & 2.61 & 2.29 & 2.39 & 2.27 & 2.32 & 2.26 & 2.30 & 2.35 \\
\hline $\mathrm{K}_{2} \mathrm{O}$ & 0.23 & 0.30 & 0.23 & 1.12 & 0.26 & 0.22 & 0.22 & 0.32 & 0.34 & 0.31 & 0.32 & 0.23 & 0.39 & 0.34 \\
\hline $\mathrm{P}_{2} \mathrm{O}_{5}$ & 0.22 & 0.11 & 0.15 & 0.38 & 0.24 & 0.20 & 0.25 & 0.21 & 0.20 & 0.22 & 0.18 & 0.26 & 0.20 & 0.20 \\
\hline Sum & 100.28 & 99.74 & 99.61 & 99.56 & 99.88 & 99.91 & 99.92 & 99.95 & 100.28 & 100.13 & 100.27 & 99.93 & 100.08 & 99.95 \\
\hline \multicolumn{15}{|c|}{ Other analyses ${ }^{b}$} \\
\hline $\mathrm{FeO}$ & 8.35 & 5.75 & 6.51 & 7.60 & 7.70 & 8.02 & 9.96 & 9.87 & 9.13 & 10.07 & 9.34 & 9.38 & 9.42 & 9.39 \\
\hline $\mathrm{Fe}_{2} \mathrm{O}_{3}$ & 5.53 & 5.69 & 5.35 & 7.85 & 5.62 & 4.79 & 4.23 & 3.76 & 3.80 & 3.70 & 3.68 & 5.55 & 4.00 & 3.72 \\
\hline $\mathrm{H}_{2} \mathrm{O}^{+}$ & 1.65 & 1.44 & 1.40 & 1.52 & 1.44 & 1.34 & 1.18 & 0.84 & 0.83 & 0.88 & 0.81 & 1.00 & 0.80 & 0.81 \\
\hline $\mathrm{H}_{2} \mathrm{O}^{-}$ & 4.50 & 3.89 & 3.57 & 3.61 & 3.63 & 3.22 & 2.48 & 1.22 & 0.93 & 1.25 & 1.07 & 1.92 & 0.72 & 0.82 \\
\hline $\mathrm{CO}_{2}$ & 7.69 & 6.19 & 5.56 & 9.35 & 7.91 & 6.52 & 7.71 & 3.91 & 3.07 & 4.03 & 2.92 & 5.24 & 2.56 & 2.55 \\
\hline
\end{tabular}

Trace element analyses (on a dried $110^{\circ} \mathrm{C}$ basis; in ppm) ${ }^{\mathrm{c}}$

XRF

\begin{tabular}{|c|c|c|c|c|c|c|c|c|c|c|c|c|c|c|}
\hline $\mathrm{Rb}$ & 3.5 & 7.4 & 4.6 & 25.3 & 4.2 & 3.6 & 2.9 & 9.4 & 9.8 & $\begin{array}{r}8.9\end{array}$ & 8.4 & 3.8 & 11.3 & $\begin{array}{c}9.3 \\
36\end{array}$ \\
\hline $\begin{array}{l}\mathrm{Sc} \\
\mathrm{V}\end{array}$ & $\begin{array}{r}38 \\
400\end{array}$ & 405 & $\begin{array}{r}41 \\
416\end{array}$ & 385 & $\begin{array}{r}39 \\
400\end{array}$ & 393 & 379 & $\begin{array}{r}37 \\
364\end{array}$ & 356 & $\begin{array}{r}35 \\
341\end{array}$ & 369 & $\begin{array}{r}39 \\
373\end{array}$ & 358 & $\begin{array}{r}36 \\
366\end{array}$ \\
\hline $\mathrm{Cr}$ & 40 & 36 & 34 & 39 & 35 & 34 & 30 & 28 & 32 & 28 & 32 & 30 & 29 & 28 \\
\hline Co & 50 & 40 & 44 & 54 & 62 & 57 & 64 & 43 & 41 & 47 & 46 & 47 & 46 & 49 \\
\hline $\mathrm{Ni}$ & 54 & 51 & 49 & 61 & 57 & 52 & 58 & 48 & 48 & 51 & 52 & 50 & 48 & 50 \\
\hline $\mathrm{Cu}$ & 199 & 219 & 198 & 123 & 226 & 198 & 195 & 185 & 188 & 182 & 187 & 202 & 198 & 186 \\
\hline $\mathrm{Zn}$ & 114 & 101 & 103 & 118 & 104 & 113 & 129 & 102 & 130 & 113 & 112 & 117 & 107 & 103 \\
\hline $\mathrm{Sr}$ & 410 & 686 & 446 & 291 & 387 & 403 & 351 & 278 & 271 & 266 & 272 & 281 & 269 & 266 \\
\hline $\mathrm{Ba}$ & 276 & 131 & 178 & 91 & 157 & 168 & 126 & 192 & 165 & 157 & 207 & 158 & 171 & 202 \\
\hline $\mathrm{Y}$ & 35 & 37 & 38 & 41 & 34 & 37 & 35 & 40 & 42 & 40 & 41 & 35 & 43 & 39 \\
\hline $\mathrm{Zr}$ & 185 & 189 & 187 & 152 & 181 & 186 & 184 & 172 & 176 & 168 & 172 & 181 & 182 & 169 \\
\hline $\mathrm{Nb}$ & 14.4 & 14.1 & 14.0 & 12.8 & 13.2 & 14.7 & 14.2 & 13.2 & 12.9 & 13.4 & 12.7 & 14.6 & 13.6 & 13.3 \\
\hline
\end{tabular}

INAA

\begin{tabular}{|c|c|c|c|c|c|c|c|}
\hline $\mathrm{La}$ & 14.2 & 15.6 & 14.6 & 15.2 & 15.2 & 13.3 & 14.3 \\
\hline $\mathrm{Ce}$ & 36.0 & 37.9 & 36.1 & 36.8 & 35.2 & 34.0 & 36.9 \\
\hline Nd & 21.0 & 21.3 & 19.3 & 18.9 & 20.3 & 19.7 & 19.7 \\
\hline Sm & 6.3 & 7.0 & 6.6 & 6.5 & 6.5 & 6.4 & 6.1 \\
\hline Eu & 2.2 & 2.3 & 2.2 & 2.1 & 2.1 & 2.3 & 2.1 \\
\hline Gd & 7.9 & 8.7 & 10.0 & 7.7 & 7.3 & 9.0 & 8.2 \\
\hline $\mathrm{Tb}$ & 1.1 & 1.3 & 1.1 & 1.4 & 1.2 & 1.2 & 1.2 \\
\hline Dy & 7.3 & 7.4 & 6.7 & 7.0 & 7.6 & 6.8 & 7.8 \\
\hline $\mathrm{Tm}$ & 0.58 & 0.59 & 0.55 & 0.63 & 0.63 & 0.46 & 0.58 \\
\hline $\mathrm{Yb}$ & 3.1 & 2.8 & 3.0 & 3.3 & 3.4 & 2.8 & 3.3 \\
\hline $\mathrm{Lu}$ & 0.38 & 0.37 & 0.38 & 0.44 & 0.43 & 0.37 & 0.43 \\
\hline Co & 45 & 39 & 57 & 39 & 42 & 43 & 43 \\
\hline $\mathrm{Cr}$ & 42 & 37 & 38 & 30 & 33 & 40 & 31 \\
\hline $\mathrm{Na}_{2} \mathrm{O}$ (wt. \%) & 2.83 & 3.02 & 3.00 & 2.74 & 2.70 & 2.82 & 2.70 \\
\hline
\end{tabular}

Note: Blanks indicate "not analyzed."

a Total $\mathrm{Fe}$ as $\mathrm{FeO}$.

b $\mathrm{On}$ a dried $\left(110^{\circ} \mathrm{C}\right)$ basis, except $\mathrm{H}_{2} \mathrm{O}^{-}$.

${ }^{\mathrm{c}} \mathrm{XRF}=\mathrm{X}$-ray fluorescence; INAA = instrumental neutron-activation analysis.

basalts ( $\mathrm{Zr} / \mathrm{Nb}$ about 13$)$ are similar to the basalts of the eastern end of the Walvis Ridge with a $\mathrm{Zr} / \mathrm{Nb}$ of about 10. "These basalts were erupted at approximately the same period.

Barker et al. (1981) noted that the Hole 516F basalts were enriched in incompatible elements compared to typical MORB (i.e. the normal or N-type of Sun et al., 1979, or Group I of Bryan et al., 1976). However, they did compare them to some of the MORB that are mark- edly enriched in incompatible elements (the plume or P-type of Sun et al., 1979, or Group II of Bryan et al., 1976), particularly those on the Reykjanes Peninsula recovered during Leg 49. Wood and others (1979) compared enriched MORB from $63^{\circ} \mathrm{N}, 45^{\circ} \mathrm{N}$, and $36^{\circ} \mathrm{N}$ and noted that each was distinctive, particularly in $\mathrm{Zr}$ / $\mathrm{Nb}$ content $\left(63^{\circ} \mathrm{N}\right.$ about $8,45^{\circ} \mathrm{N}$ about $5,36^{\circ} \mathrm{N}$ about $3)$. These LREE-enriched MORB have been characterized by Schilling (1973) as plume-type basalts. However, 
Table 2. Average composition for upper and lower parts of DSDP Hole 516F.

\begin{tabular}{lrr}
\hline Element & $\begin{array}{r}\text { Group } 1^{\mathrm{a}} \text { average } \\
\text { (upper) }\end{array}$ & $\begin{array}{c}\text { Group } 2^{\mathrm{b}} \text { average } \\
\text { (lower) }\end{array}$ \\
\hline Major elements (in wt.\%) & \\
$\mathrm{SiO}_{2}$ & 49.74 & 51.22 \\
$\mathrm{TiO}_{2}$ & 2.67 & 2.35 \\
$\mathrm{Al}_{2} \mathrm{O}_{3}$ & 16.14 & 14.10 \\
$\mathrm{FeO}^{\mathrm{c}}$ & 12.39 & 13.14 \\
$\mathrm{MnO}$ & 0.14 & 0.21 \\
$\mathrm{MgO}$ & 4.74 & 5.73 \\
$\mathrm{CaO}$ & 10.74 & 10.49 \\
$\mathrm{Na} 2 \mathrm{O}$ & 2.90 & 2.31 \\
$\mathrm{~K}_{2} \mathrm{O}$ & 0.24 & 0.32 \\
$\mathrm{P}_{2} \mathrm{O}_{5}$ & 0.20 & 0.21 \\
$\mathrm{FeO}$ & 7.72 & 9.51 \\
$\mathrm{Fe}_{2} \mathrm{O}_{3}$ & 5.20 & 4.03 \\
$\mathrm{H}_{2} \mathrm{O}+$ & 1.41 & 0.85 \\
$\mathrm{CO}_{2}$ & 6.95 & 3.47
\end{tabular}

Trace elements (in ppm)

\begin{tabular}{|c|c|c|}
\hline $\mathrm{Rb}$ & 4.4 & 8.7 \\
\hline $\mathrm{Sc}$ & 39 & 37 \\
\hline V & 399 & 361 \\
\hline $\mathrm{Cr}$ & 35 & 30 \\
\hline Co & 53 & 46 \\
\hline $\mathrm{Ni}$ & 54 & 50 \\
\hline $\mathrm{Cu}$ & 206 & 190 \\
\hline $\mathrm{Zn}$ & 111 & 112 \\
\hline $\mathrm{Sr}$ & 447 & 272 \\
\hline $\mathrm{Ba}$ & 173 & 179 \\
\hline $\mathrm{Y}$ & 36 & 40 \\
\hline $\mathrm{Zr}$ & 185 & 174 \\
\hline $\mathrm{Nb}$ & 14.1 & 13.4 \\
\hline $\mathrm{La}$ & 14.8 & 14.5 \\
\hline $\mathrm{Ce}$ & 36.7 & 35.7 \\
\hline $\mathrm{Nd}$ & 20.3 & 19.7 \\
\hline $\mathrm{Sm}$ & 6.6 & 6.4 \\
\hline Eu & 2.2 & 2.1 \\
\hline Gd & 8.9 & 8.1 \\
\hline $\mathrm{Tb}$ & 1.2 & 1.2 \\
\hline Dy & 7.1 & 7.3 \\
\hline $\mathrm{Tm}$ & 0.57 & 0.57 \\
\hline $\mathrm{Yb}$ & 3.0 & 3.2 \\
\hline $\mathrm{Lu}$ & 0.38 & 0.42 \\
\hline \multicolumn{3}{|c|}{$\begin{array}{l}\text { Average of } 6 \text { samples (core-section, depth in cm): } \\
126-2,143 ; 126-3,6 ; 126-3,41 ; 127-3,68 ; 127-3,97 \text {; } \\
127-4,44 \text {. Sample } 127-2,83 \mathrm{~cm} \text { has been omitted } \\
\text { from the average of Group } 1 \text { because it contains a } \\
\text { high quantity of green smectite (see text for further } \\
\text { explanation). } \\
\text { Average of } 7 \text { samples (core-section, depth in cm): } \\
127-4,60 ; 128-1,25 ; 128-1,122 ; 128-2,51 ; 128-2 \text {, } \\
130 ; 128-3,44 ; 128-3,73 \text {. Rare earth elements and } \\
\text { Sc are average of } 3 \text { samples for Group } 1 \text {, and } 4 \text { for } \\
\text { Group } 2 \text { (see Table } 1 \text {, Part } 2 \text { ). } \\
\text { Total Fe as FeO. }\end{array}$} \\
\hline
\end{tabular}

in detail there are significant differences in rare-earth (RE) patterns among hot spots as well (Schilling et al., 1982). The RE pattern of Hole $516 \mathrm{~F}$ basalts are similar to Mid-Atlantic Ridge basalts over the Azores platform in terms of light and heavy RE enrichments, but are slightly higher in the middle RE (Sm-Eu-Gd). In a recent study of the Mid-Atlantic Ridge axis about $30-45^{\circ} \mathrm{S}$, Schilling and others (1981) noted that most of the basalts were typical MORB. Those recovered from the axis at the latitude of Tristan da Cunha, however, were slight- ly enriched in incompatible elements $(\mathrm{Zr} / \mathrm{Nb}$ about 16 , slight LREE enrichment), although the enrichment was neither so great nor so distinctive as that of the Rio Grande Rise basalts.

\section{Origin of Rio Grande Rise}

The age of Hole $516 \mathrm{~F}$ basalts is compatible with an origin at a spreading center about $84 \mathrm{Ma}$ ago. However, unlike the Mid-Atlantic Ridge basalts at about $30^{\circ} \mathrm{S}$ (DSDP Leg 3), these basalts are not typical MORB. The shallow water origin, the probable past history of the Rio Grande Rise as a complex of subaerial volcanoes (Thiede, 1974), and the presence of typical alkaline volcanic material at least through to the Eocene (Fodor and Thiede, 1977) all suggest that the Rio Grande Rise may have followed a pattern typical of other large volcanoes in Hawaii, Iceland, or Piton de la Fournaise of Réunion Island, which started with tholeiitic eruptives in the early stages and then changed to alkaline basalts in the later stages.

The similarity of the Hole $516 \mathrm{~F}$ basalts to the eastern Walvis Ridge basalts suggests that the two basalts may have had similar origins. At the opening of the Atlantic from 80-100 Ma, the hot spot (which was the origin of the Walvis and Rio Grande rises) apparently was mildly tholeiitic in character. As the spreading continued, the hot spot has grown more alkaline; Tristan da Cunha is the present-day expression. Alternatively, one might argue that the eastern Walvis and the Rio Grande Rise at Site 516 were not direct expressions of the hot spot but rather of a spreading center influenced by a nearby hot spot such as the present-day Mid-Atlantic Range axis adjacent to Tristan da Cunha (Schilling et al., 1981).

Another possible origin is volcanism associated with the large fracture zones bounding the Rio Grande Rise (and the Walvis Ridge) (LePichon and Hayes, 1971). Kempe and Schilling (1976) related the Discovery Tablemount chemistry to a possible hot-spot origin, and noted that, because it was much younger than the surrounding sea floor, it had an origin not directly connected with spreading. The basement age for Hole $516 \mathrm{~F}$ is consistent with a spreading model, but the Eocene breccia in Site 357 and the Eocene tuff at Site $\mathbf{3 5 9}$ on the Walvis Ridge (Fodor, Keil, et al., 1977) suggest that volcanism continued on these aseismic ridges until they were well away from the spreading centers.

The chemistry, the morphology, and the age relationships strongly suggest an origin either adjacent to a hot spot or related to spreading at a hot spot. The comparison with the corresponding part of the Walvis Ridge suggests the hot-spot influence has continued through time, producing a linear series of volcanoes that continued their activity and development as they moved away from the spreading center. The strongly alkaline character of the present-day Tristan da Cunha volcanism, with its unusually potassic eruptives, suggests that the hotspot activity may have intensified with time.

\section{ACKNOWLEDGMENTS}

We thank DSDP for access to Leg 72 core samples. We also thank Dr. F. A. Frey for use of unpublished rare-earth element data on some Walvis Ridge samples, Dr. Fodor for making available the dredged samples from the Rio Grande Rise, and Drs. Bryan and Fodor for re- 


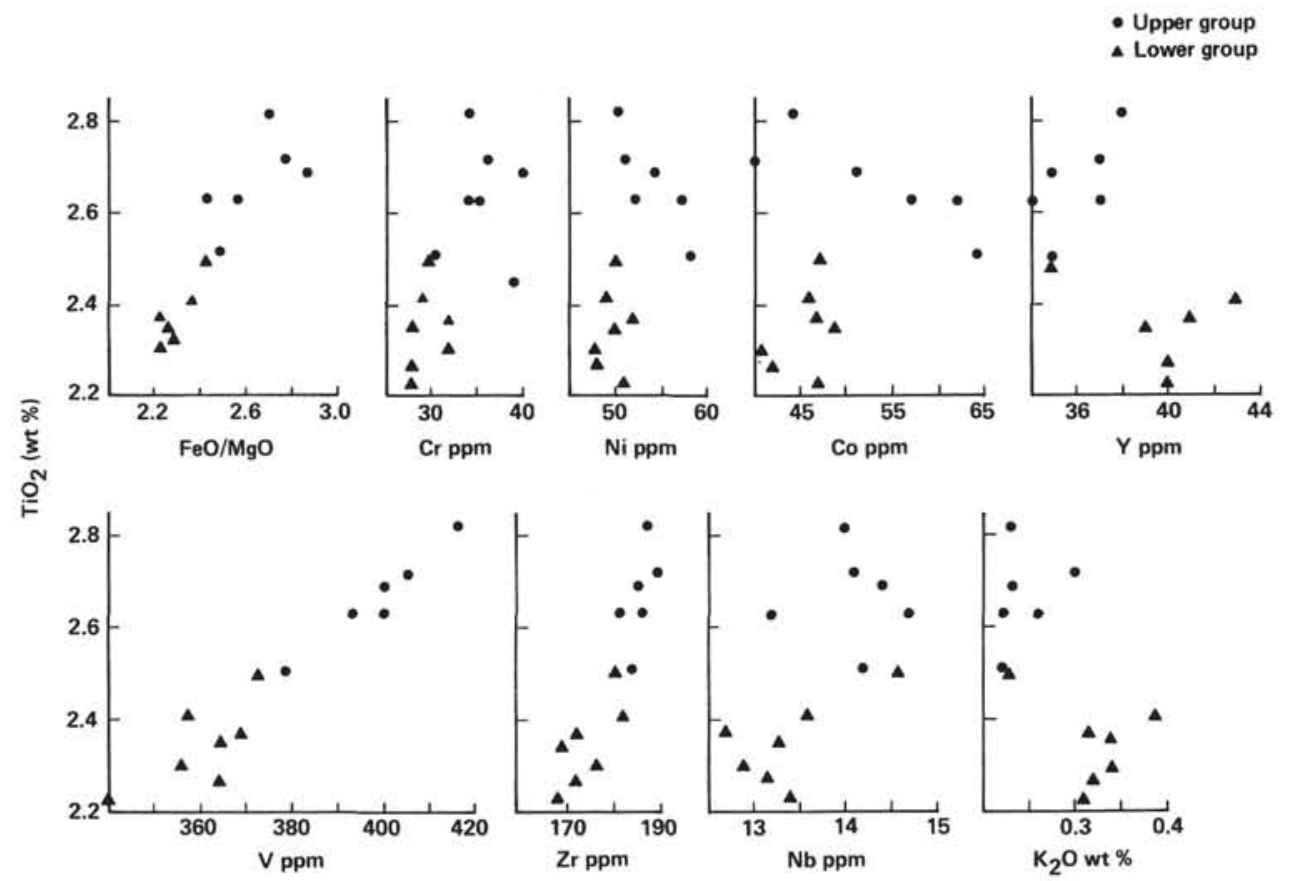

Figure 2. Plot of $\mathrm{TiO}_{2}$ versus $\mathrm{FeO} / \mathrm{MgO}, \mathrm{Cr}, \mathrm{Ni}, \mathrm{Co}, \mathrm{Y}, \mathrm{V}, \mathrm{Zr}, \mathrm{Nb}$, and $\mathrm{K}_{2} \mathrm{O}$ for upper and lower groups of DSDP Leg 72 Hole 516F. Upper group = samples from 516F-126-2, 143-146 cm to $516 \mathrm{~F}-127-4,44-$ $48 \mathrm{~cm}$; lower group = samples from $516 \mathrm{~F}-127-4,60-63 \mathrm{~cm}$ to the bottom of the hole.

views of this manuscript. Grateful acknowledgment is made to Margaret Sulanowska, Brian Schroeder, and Don Bankston for their help in the core sampling and analyses. This work was supported by NSF grants OCE 77-26842 (supplement) and OCE 80-24629 to Woods Hole Oceanographic Institute and OCE 78-24690 to University of Rhode Island. This is contribution No. 5026 from the Woods Hole Oceanographic Institution.

\section{REFERENCES}

Baker, P. E., Gass, I. G., Harris, P. G., and LeMaitre, R. W., 1964. The volcanological report of the Royal Society Expedition to Tristan da Cunha, 1962. Phil. Trans. R. Soc. London Ser. A, 256: 439-578.

Barker, P.F., and Shipboard Scientific Party, 1981. Deep Sea Drilling Project Leg 72: Southwest Atlantic paleocirculation and Rio Grande Rise tectonics. Geol. Soc. Am. Bull., 92:294-309.

Bryan, W. B., 1972. Morphology of quench crystals in submarine basalts. J. Geophys. Res., 77:5812-5819.

Bryan, W. B., Thompson, G., Frey, F., and Dickey, J. S., 1976. Inferred geologic settings and differentiation in basalts from the Deep Sea Drilling Project. J. Geophys. Res., 81:4285-4304.

Dietz, R. S., and Holden, J. C., 1970. Reconstruction of Pangaea: spreading and dispersion of continents, Permian to Recent. $J$. Geophys. Res., 75:4939-4956.

Erlank, A. J., and Kable, E. J. D., 1976. The significance of incompatible elements in Mid-Atlantic Ridge basalts from $45^{\circ} \mathrm{N}$ with particular reference to $\mathrm{Zr} / \mathrm{Nb}$. Contrib. Mineral. Petrol., 54: 281-291.

Frey, F. A., Bryan, W. B., and Thompson, G., 1974. Atlantic Ocean Floor: geochemistry and petrology of basalts from Legs 2 and 3 of the Deep Sea Drilling Project. J. Geophys. Res., 79:5507-5527.

Fodor, R. V., Husler, J. W., and Kumar, N., 1977. Petrology of volcanic rocks from an aseismic rise: implications for the origin of the Rio Grande Rise, South Atlantic Ocean. Earth Planet. Sci. Lett., 35:225-233.

Fodor, R. V., Keil, K., Husler, J. W., and McKee, E. H., 1977. Petrology and $\mathrm{K}-\mathrm{Ar}$ age of volcanic tuff and ash from the Walvis Seamount Province, DSDP Site 359. In Supko, P. R., Perch-Nielsen, K., et al., Init. Rpts. DSDP, 39: Washington (U.S. Govt. Printing Office), 525-536.
Fodor, R. V., and Thiede, J., 1977. Volcanic breccia from DSDP Site 357: implications for the composition and origin of the Rio Grande Rise. In Supko, P. R., Perch-Nielsen, K., et al., Init. Rpts. DSDP, 39: Washington (U.S. Govt. Printing Office), 537-544.

Hekinian, R., 1972. Volcanics from the Walvis Ridge in the southeast Atlantic Ocean. Nature, 239:91-93.

Hekinian, R., and Thompson, G., 1976. Comparative geochemistry of volcanics from rift valleys, transform faults and aseismic ridges. Contrib. Mineral. Petrol., 57:145-162.

Humphris, S. E. and Thompson, G., 1982. A geochemical study of rocks from the Walvis ridge, South Atlantic. Chem. Geol., 36: 253-274.

Kempe, D. R. C., and Schilling, J.-G., 1974. Discovery Tablemount basalt: petrology and geochemistry. Contrib. Mineral. Petrol., 44:101-115.

LeMaitre, R. W., 1962. Petrology of volcanic rocks, Gough Island, South Atlantic. Geol. Soc. Am. Bull., 73:1309-1340.

LePichon, X., and Hayes, D. E., 1971. Marginal offsets, fracture zone and the early opening of the South Atlantic. J. Geophys. Res., 76:6283-6296.

Macdonald, G. A., and Katsura, T., 1964. Chemical composition of Hawaiian lavas. J. Petrology, 5:82-133.

Maxwell, A. E., Von Herzen, R. P., Hsü, K. J., Andrews, J. E., Saito, T., Percival, S. E., Jr., Milow, E. D., and Boyce, R. E., 1970. Deep Sea Drilling in the South Atlantic. Science, 168: 1047-1059.

Morgan, W. J., 1971. Convection plumes in the mantle. Nature, 230:42-48.

Perch-Nielsen, K., Supko, P. R., and Shipboard Scientific Party, 1977. Site Report 357. In Supko, P. R., Perch-Nielsen, K., et al., Init. Repts. DSDP, 39: Washington (U.S. Govt. Printing Office), 231-328.

Schilling, J.-G., 1973. Iceland mantle plume: geochemical study of Reykjanes Ridge. Nature, 242:565-571.

1975. Rare-earth variations across "normal segments" of the Reykjanes Ridge, $60^{\circ}-53^{\circ} \mathrm{N}$, Mid-Atlantic Ridge, $29^{\circ} \mathrm{S}$ and East Pacific Rise $2^{\circ}-19^{\circ} \mathrm{S}$, and evidence on the composition of the underlying low-velocity layer. J. Geophys. Res., 80:1459-1473.

Schilling, J.-G., Kingsley, R., Humphris, S. E., and Thompson, G., 1981. Tristan da Cunha hot spot. EOS Trans. Am. Geophys. Union, 62:424. 
Schilling, J.-G., and Ridley, W. I., 1975. Volcanic rocks from DSDP Leg 29: Petrography and rare earth abundances. In Kennett, J. P., Houtz, R. E., et al., Init. Repts. DSDP, 29: Washington (U.S. Govt. Printing Office), 1103-1197.

Schilling, J.-G., Zajac, M., Evans, R., Johnston, T., White, W., Devine, J. D., and Kingsley, R., in press. Petrological and geochemical variations along the Mid-Atlantic Ridge from $29^{\circ} \mathrm{N}$ to $73^{\circ}$ N. Am. J. Sci.

Schroeder, B., Thompson, G., Sulanowska, M., and Ludden, J. N., 1980. Analysis of geologic materials using an automated x-ray fluorescence system. X-ray Spectrom., 9:198-205.

Sun, S. S., Nesbitt, R. W., and Sharaskin, A. Y., 1979. Chemical characteristics of mid-ocean ridge basalts. Earth Planet. Sci. Lett., 44:119-138.

Thiede, J., 1977. Subsidence of aseismic ridges: evidence from sediments on Rio Grande Rise (Southwest Atlantic Ocean). Am. Assoc. Pet. Geol. Bull., 61:929-940.
Thompson, G., 1973. A geochemical study of the low temperature interaction of seawater and oceanic igneous rocks. EOS Trans. Am. Geophys. Union, 54:1015-1019.

Wood, D. A., Tarney, J., Vanet, J., Saunders, A. J., Bougault, H., Joran, J. C., Treuil, M., and Cann, J. R., 1979. Geochemistry of basalts drilled in the North Atlantic by IPOD Leg 49: implications for mantle heterogeneity. Earth Planet. Sci. Lett., 42:77-97.

Zielinski, R. A., and Frey, F. A., 1970. Gough Island: evaluation of a fractional crystallization model. Contrib. Mineral. Petrol., 29: 242-254.

Date of Initial Receipt: Decembèr 11, 1981

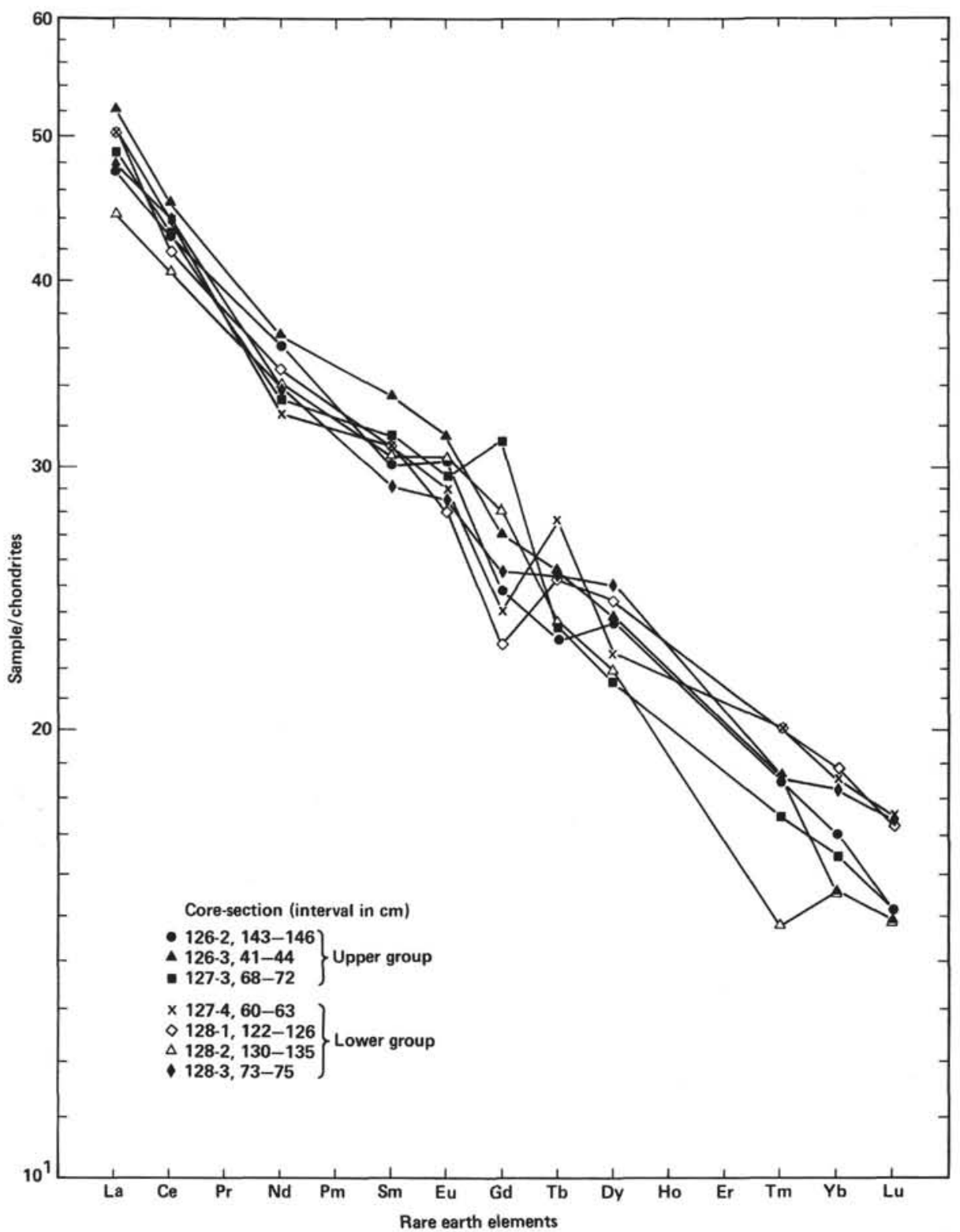

Figure 3. Plot of chondrite-normalized rare-earth element abundances for Hole 516F. 


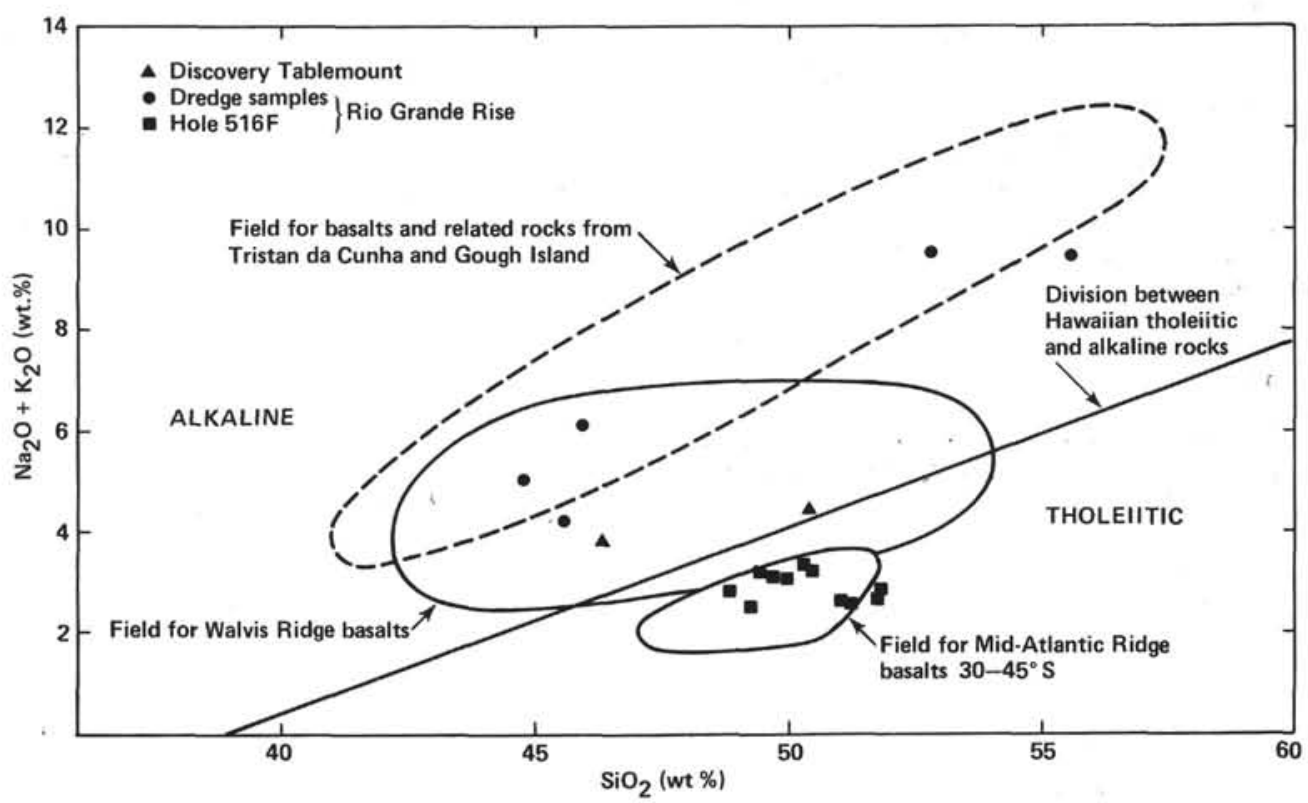

Figure 4. $\mathrm{Na}_{2} \mathrm{O}+\mathrm{K}_{2} \mathrm{O}$ versus $\mathrm{SiO}_{2}$ diagram showing the fields of alkaline and tholeitic basalts (after Macdonald and Katsura, 1964). The field for basalts from Tristan da Cunha and Gough Island are from data of Baker et al. (1964), LeMaitre (1962), and Humphris and Thompson (1982); the data for the Walvis Ridge are from Hekinian (1972) and Humphris and Thompson (1982); the data for Mid-Atlantic Ridge basalts are from Frey and others (1974), Humphris and Thompson (1982), and Schilling and others (1981); Discovery Tablemount data are from Kemp and Schilling (1974); data for dredge samples are from Fodor, Husler, and Kumar (1977); and data for Hole 516F are from this paper.

Table 3. Comparative analyses of Hole $516 \mathrm{~F}$ basalts with other basalts from the South Atlantic.

\begin{tabular}{|c|c|c|c|c|c|c|}
\hline Element & $\begin{array}{c}\text { Hole } 516 \mathrm{~F} \\
\text { Rio Grande Rise }\end{array}$ & $\begin{array}{c}\text { Dredge RC16 } \\
\text { Rio Grande Rise }\end{array}$ & $\begin{array}{l}\text { Discovery } \\
\text { Tablemount }\end{array}$ & $\begin{array}{l}\text { E. Walvis } \\
\text { Ridge }\end{array}$ & $\begin{array}{c}\text { Tristan da } \\
\text { Cunha }\end{array}$ & $\begin{array}{l}\text { Mid-Atlantic Ridge, } \\
\text { S. Atlantic }\end{array}$ \\
\hline \multicolumn{7}{|c|}{ Major element oxides (in wt. \%) } \\
\hline $\mathrm{SiO}_{2}$ & 50.48 & 47.33 & 51.53 & 51.14 & 46.7 & 50.74 \\
\hline $\mathrm{TiO}_{2}$ & 2.51 & 3.25 & 2.75 & 3.03 & 3.6 & 1.03 \\
\hline $\mathrm{Al}_{2} \mathrm{O}_{3}$ & 15.12 & 14.90 & 15.86 & 16.53 & 17.3 & 15.83 \\
\hline $\mathrm{FeO}$ & 12.76 & 9.60 & 9.82 & 11.96 & 10.4 & 9.05 \\
\hline $\mathrm{MnO}$ & 0.17 & 0.17 & 0.16 & & & 0.15 \\
\hline $\mathrm{MgO}$ & 5.23 & 7.19 & 4.99 & 2.37 & 4.7 & 8.78 \\
\hline $\mathrm{CaO}$ & 10.61 & 10.15 & 9.28 & 7.08 & 9.7 & 12.20 \\
\hline $\mathrm{Na}_{2} \mathrm{O}$ & 2.61 & 3.57 & 3.10 & 2.91 & 4.1 & 2.32 \\
\hline $\mathrm{K}_{2} \mathrm{O}$ & 0.28 & 1.73 & 1.43 & 2.19 & 3.0 & 0.06 \\
\hline $\mathrm{P}_{2} \mathrm{O}_{5}$ & 0.21 & 0.75 & 0.43 & & & \\
\hline \multicolumn{7}{|c|}{ Trace elements (in ppm) } \\
\hline $\mathrm{Rb}$ & 6.5 & 2.8 & 22 & & 173 & \\
\hline $\mathrm{Sc}$ & 38 & & 22.5 & & & 42 \\
\hline v & 380 & 271 & 400 & 437 & 230 & 233 \\
\hline $\mathrm{Cr}$ & 32 & 146 & 50 & 73 & 28 & 500 \\
\hline Co & 49 & 45 & 40 & 62 & 18 & 49 \\
\hline $\mathrm{Ni}$ & 52 & 106 & 100 & 55 & 10 & 174 \\
\hline $\mathrm{Cu}$ & 198 & 55 & 225 & 110 & & 102 \\
\hline $\mathrm{Zn}$ & 112 & 103 & 227 & & & \\
\hline $\mathrm{Sr}$ & 360 & 928 & $>1000$ & 318 & 1167 & 124 \\
\hline $\mathrm{Ba}$ & 176 & 1156 & 600 & 384 & 913 & 13 \\
\hline $\mathrm{Y}$ & 38 & 25 & 50 & 46 & 45 & 35 \\
\hline $\mathrm{Zr}$ & 180 & 293 & 250 & 200 & 325 & 91 \\
\hline $\mathrm{Nb}$ & 13.7 & 70 & & & 112 & \\
\hline $\mathrm{La}$ & 14.7 & & 29.4 & 25.1 & 196 & 2.2 \\
\hline $\mathrm{Ce}$ & 36.2 & & & 65 & & 7.1 \\
\hline Nd & 20.0 & & & 35.2 & & 7.2 \\
\hline $\mathrm{Sm}$ & 6.5 & & 7.8 & 8.3 & & 2.41 \\
\hline Eu & 2.2 & & 2.4 & 2.5 & & 0.93 \\
\hline Gd & 8.5 & & & & & \\
\hline $\mathrm{Tb}$ & 1.2 & & 1.0 & 1.2 & & 0.69 \\
\hline Dy & 7.2 & & & & & \\
\hline $\mathrm{Tm}$ & 0.57 & & & & & \\
\hline $\mathrm{Yb}$ & 3.1 & & 1.5 & 3.3 & & 2.8 \\
\hline Lu & 0.40 & & 0.29 & 0.53 & & 0.49 \\
\hline
\end{tabular}

Note: Hole $516 \mathrm{~F}$ column $=$ mean of Groups 1 and 2, Table 2 (this paper). Dredge RC16 column $=$ mean of 3 basalts, D11A, D12C, and D12A (Fodor. Husler, et al., 1977); trace element data previously unpublished. Discovery Table-mount colD12C, and D12A (Fodor, Husler, et al., 1977); trace element data previously unpublished. Discovery Table-mount col-
umn $=$ fresh basalt (Kemp and Schilling, 1974). E. Walvis Ridge column $=$ mean of 7 basalts (Hekinian, 1972; Hekinian umn $=$ fresh basalt (Kemp and Schilling, 1974). E. Walvis Ridge column $=$ mean of 7 basalts (Hekinian, 1972; Hekinian
and Thompson, 1976; REE from Frey, unpublished). Tristan da Cunha column $=$ average of 10 analyses (Baker et al., 1964). Mid-Atlantic Ridge column $=$ average of 7 basalt glass analyses, DSDP Leg 3 (Frey et al., 1974). 


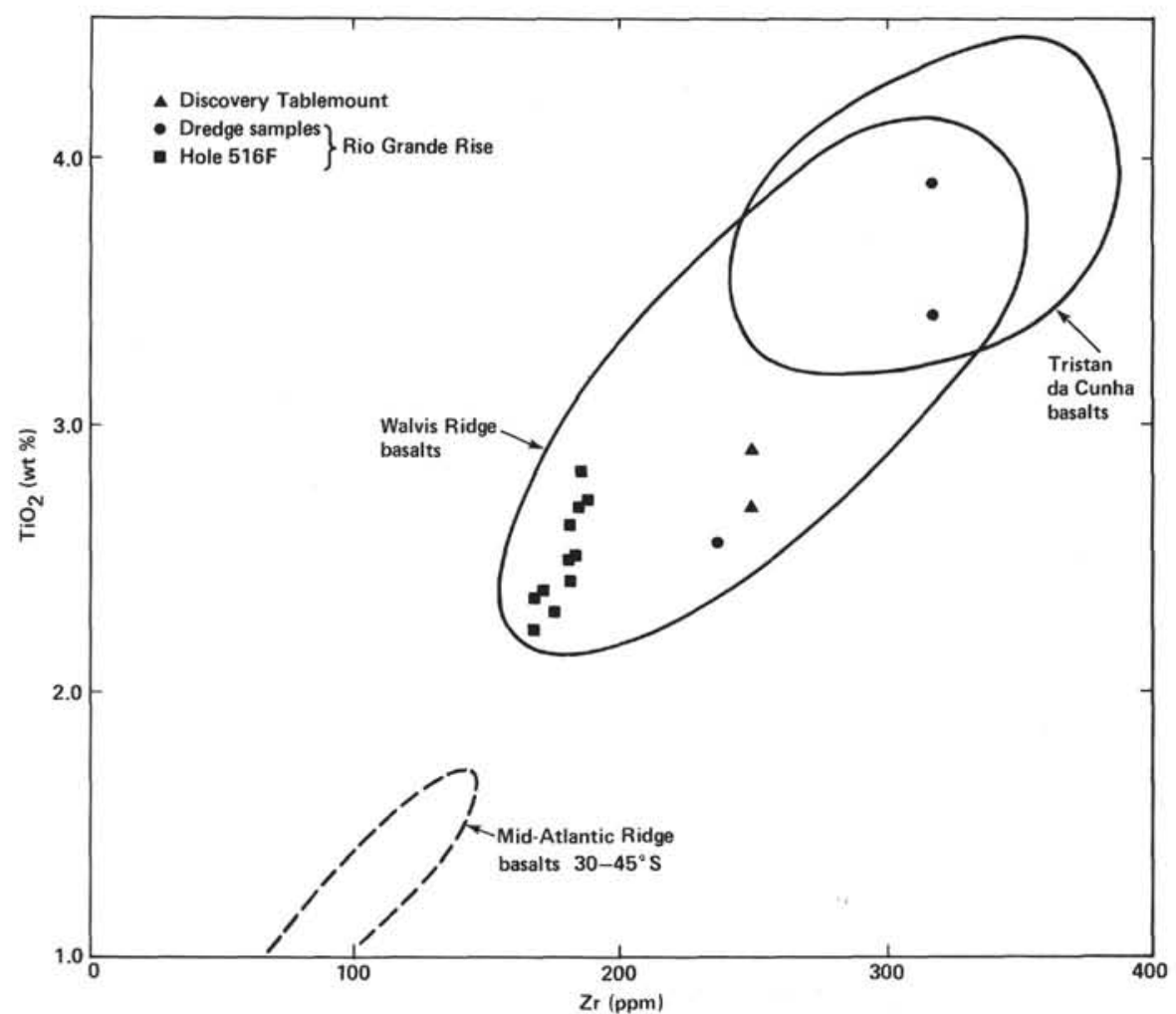

Figure 5. Plot of $\mathrm{TiO}_{2}$ versus $\mathrm{Zr}$ for Hole $516 \mathrm{~F}$ and other basalts. Data sources as in Figure 4.

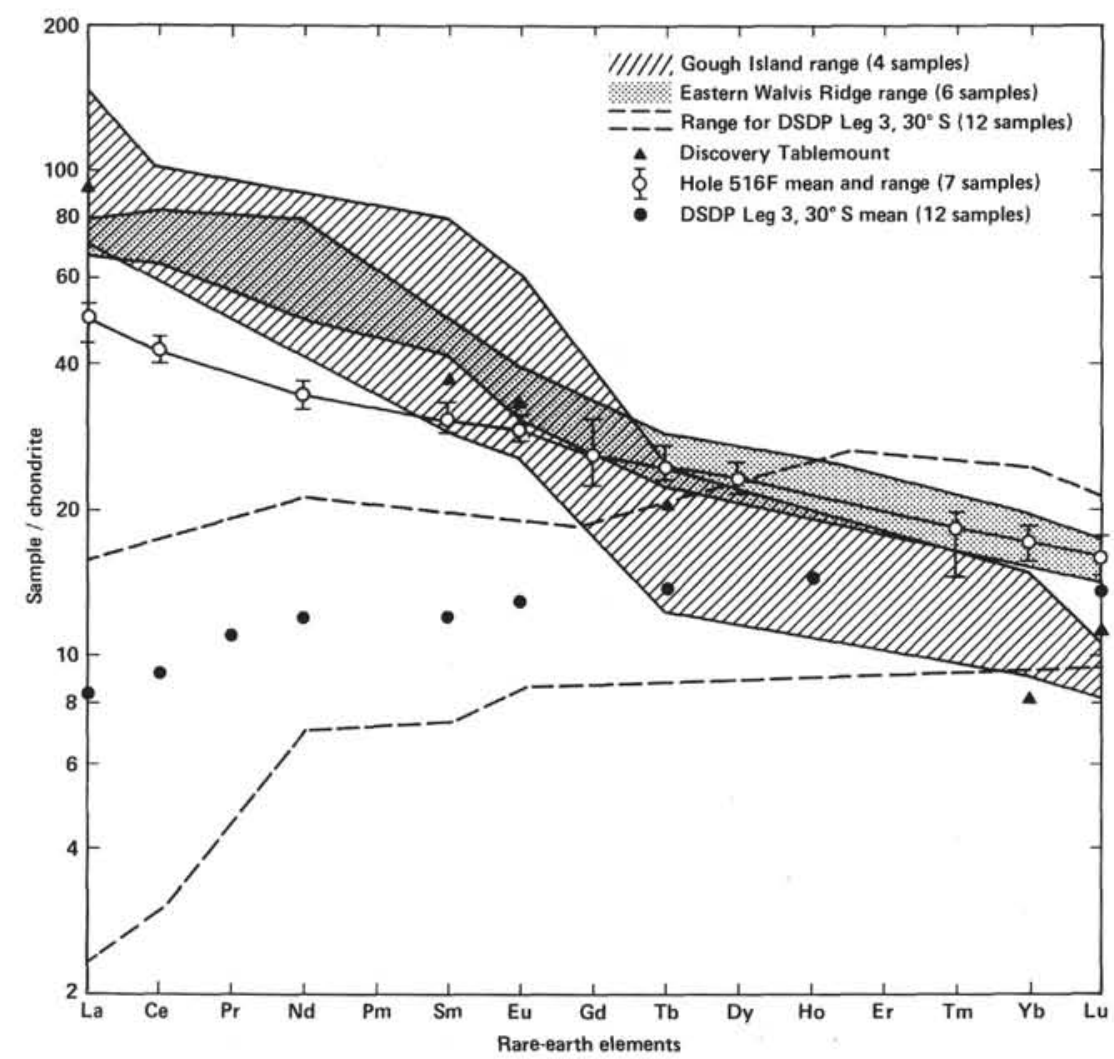

Figure 6. Chondrite-normalized REE data for Hole 516F basalts and other basalts. Data for Gough Island are from Zielinski and Frey (1970); for the Walvis Ridge the data are for the dredge samples described by Hekinian (1972) for the eastern end of the Walvis Ridge and are from Frey (personal communication); the remainder of the data sources as in Figure 4. 
Table 4. Trace element analyses of dredged samples from Rio Grande Rise (in ppm)

\begin{tabular}{lrrrrr}
\hline Element & D11A & D12C & D12A & D12B & D12D \\
\hline $\mathrm{Rb}$ & 33 & 30 & 20 & 84 & 97 \\
$\mathrm{~V}$ & 235 & 268 & 309 & 180 & 96 \\
$\mathrm{Cr}$ & 246 & 36 & 157 & $<2$ & 4 \\
$\mathrm{Co}$ & 48 & 46 & 42 & 13 & 17 \\
$\mathrm{Ni}$ & 139 & 83 & 102 & 14 & 14 \\
$\mathrm{Cu}$ & 52 & 38 & 76 & 3 & 20 \\
$\mathrm{Zn}$ & 75 & 130 & 105 & 111 & 92 \\
$\mathrm{Sr}$ & 878 & 1028 & 879 & 1211 & 1045 \\
$\mathrm{Ba}$ & 927 & 1197 & 1345 & 1615 & 2727 \\
$\mathrm{Y}$ & 23 & 30 & 23 & 34 & 34 \\
$\mathrm{Zr}$ & 236 & 322 & 322 & 450 & 417 \\
$\mathrm{Nb}$ & 43 & 73 & 95 & 77 & 83 \\
\hline
\end{tabular}

Note: Major element analyses presented by Fodor, Husler, et al. (1977); trace element analyses on splits from those samples.

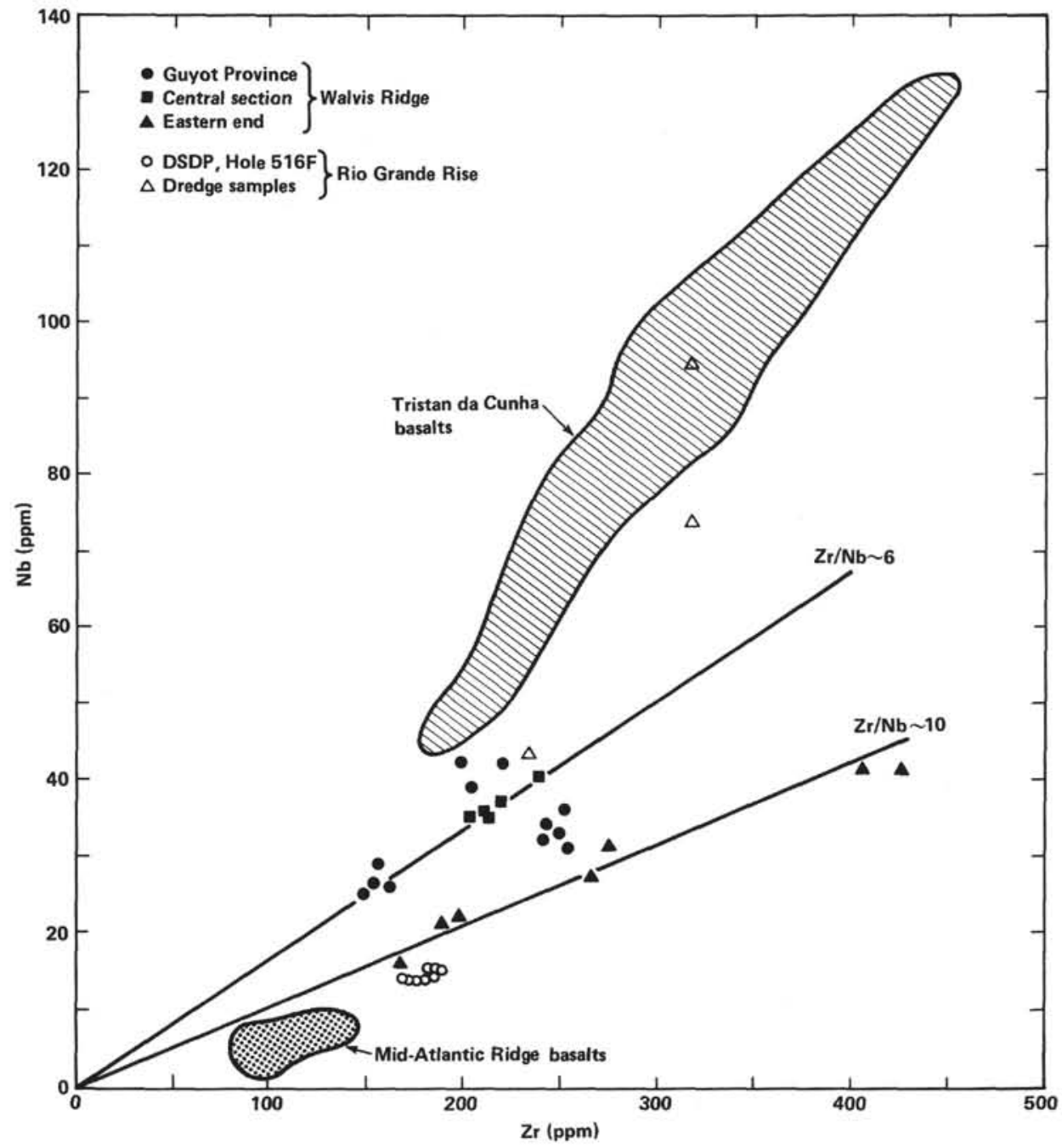

Figure 7. Plot of $\mathrm{Nb}$ versus $\mathrm{Zr}$ for Hole $516 \mathrm{~F}$ basalts and other basalts. Data for Tristan da Cunha and the Walvis Ridge are from Humphris and Thompson (1982); the remainder of the data sources as in Figure 4. 